\title{
lleal interposition surgery for treatment of type 2 diabetes mellitus-pros and cons
}

\author{
M. Payab ${ }^{1}$ and Sh. Hasani-Ranjbar ${ }^{1,2^{*}}$
}

\begin{abstract}
Nowadays, the surgical techniques for treating type 2 diabetes (T2DM) include: Ileal Interposition (II), Ileal Interposition in combination with Sleeve Gastrectomy (IISG) and Diverted Sleeve Gastrectomy (IIDSG). These procedures are not only for obese subjects, but are also used for non-obese subjects. These types of surgical procedures can improve glycemic control, and lead to a significant reduction in oral hypoglycemic agents (OHAs) and insulin therapy. The results of various studies have shown the safety, feasibility, and efficacy of the surgical procedure for the treatment of T2DM. Although it is an effective treatment option, this procedure is not recommended for general use and long-term studies are needed to confirm these findings and potential side effects on a larger number of patients.
\end{abstract}

\section{Background}

Obesity, type 2 diabetes (T2DM) and metabolic disorders are the most major health problems with an increasing prevalence globally. The two latter complications are directly related to the obesity, while some other complications are results of metabolic abnormality associated with obesity $[1,2]$.

Diabetes mellitus is a chronic disease and a common cause of morbidity and mortality around the world. The global prevalence of diabetes among adults (aged 2079 years) in 2010 was $6.4 \%$ (285 million adults) [3]. Also, world Health Organization (WHO) has reported that by 2030, the prevalence of T2DM will increase to 336 million subjects [4]. Considering the global health crisis of diabetes and obesity in this era and the need for an effective treatment of patients, surgery can be proposed in addition to drug therapy (Synthetic and Medicinal plants) $[5,6]$.

In the past, other surgical procedures including sleeve gastrectomy (SG), gastric banding, Roux-en-Y-Gastric Bypass (RYGB) and Jejuno-Ileal Bypass (JIB) were used to treat diabetes. But today, other surgical procedures have been modified to achieve the maximum remission

\footnotetext{
* Correspondence: Sh_hasani@sina.tums.ac.ir

'Obesity and Eating Habits Research Center, Endocrinology and Metabolism Molecular -Cellular Sciences Institute, Tehran University of Medical Sciences, Tehran, Iran

${ }^{2}$ Endocrinology and Metabolism Research Center, Endocrinology and

Metabolism Clinical Sciences Institute, Tehran University of Medical Sciences,
} Tehran, Iran

(C) 2015 Payab and Hasani-Ranjbar. Open Access This article is distributed under the terms of the Creative Commons Attribution 4.0 International License (http://creativecommons.org/licenses/by/4.0/), which permits unrestricted use, distribution, and reproduction in any medium, provided you give appropriate credit to the original author(s) and the source, provide a link to the Creative Commons license, and indicate if changes were made. The Creative Commons Public Domain Dedication waiver (http://creativecommons.org/publicdomain/zero/1.0/) applies to the data made available in this article, unless otherwise stated.

\section{Main text}

Ileal Interposition is not only specifically a bariatric surgery, but also is used to treat diseases that target the metabolic syndrome such as T2DM. Moreover, both foregut (excluding of the duodenum) and hindgut mechanisms are utilized in these procedures $[11,14,15]$. These procedures not only for obese subjects, but is also used for non-obese subjects $[8,16-18]$.

Several studies have shown that these types of surgical procedures can improve glycemic control, (including reductions in HbA1c, fasting blood glucose (FBG), postprandial glucose (PPG)) and also may improve the metabolic parameters. These results persisted in all patients during the 3-year follow-up [12, 16-18].

Weight loss by these procedures was attributed to the increased release of peptides secreted in the ileum, GLP-1 and peptide YY (PYY), which has anorectic effects [19]. In the ileal interposition procedure, earlier exposure of food to ileum and rapid stimulation of the interposed ileal segment by ingested food leads to augmented glucagonlike peptide 1 (GLP-1) secretion [12, 17]. GLP-1 resulted in delaying gastric emptying, promotes satiety, suppressing 
appetite, inhibiting glucagon secretion, decreasing gluconeogenesis, and stimulating the glycogenesis $[20,21]$.

Ghrelin stimulates the secretion of hyperglycemic hormones such as glucagon, cortisol and growth hormone and also inhibit insulin secretion. Ghrelin is an orexigenic hormone (appetite stimulant). In the SG component of the IISG and IIDSG procedures, serum level of ghrelin is reduced and patients feel satiety and restrict their caloric intake [22-24].

Ileal Interposition is a procedure that does not lead to malabsorption. In IIDSG procedure, duodenum and part of the jejunum are bypassed and can cause malabsorption. All patients are recommended to take iron, calcium, B12, and multivitamins supplementation regularly $[12,25]$.

De paula et al. in their study have reported objective improvement of retinopathy and symptomatic improvement in neuropathy [18]. Also, other studies have reported that after the metabolic surgery, a significant reduction in oral hypoglycemic agents (OHAs) and insulin therapy was observed for glycemic control $[11,17,18]$.

Usually, patients with shorter duration of diabetes, higher BMI (Body Mass Index) and higher C-peptide level respond better to these surgical procedures [11, 26, 27].

In some studies minor and early postoperative complications such as vomiting, esophagitis, bowel obstruction, gout, and urinary tract infection have been observed. But so far, no major long-term surgical complications have been reported $[18,23]$. In advanced T2DM, iatrogenic hypoglycemia can be a limiting factor for these procedures [28].

In a study published recently, Ugale et al. introduced a novel tool known as Diabetes Remission Score (DRS) for choosing the type of surgery and predicting diabetes remission following IISG or IIDSG. The study aimed at presenting an effective and useful method based on parameters such as the duration of diabetes, BMI and stimulated C-peptide response prior to surgery for predicting post surgery diabetes remission [8]. The DRS included three grades as grade 1 (mild, DRS 7-8), grade 2 (moderate, 9-11) and grade 3 (severe, DRS 12-14). Higher scores could be associated with lower chance of remission.

In conclusion, the results of various studies have shown the safety, feasibility, and efficacy of the surgical procedure for the treatment of T2DM. Although it is an effective treatment option, this procedure is not recommended for general use and long-term studies are needed to confirm these findings and potential side effects on a larger number of patients.

\section{Abbreviations}

T2DM: Type 2 diabetes mellitus; II: Ileal Interposition; ISG: Ileal Interposition Sleeve Gastrectomy; IIDSG: Ileal Interposition Diverted Sleeve Gastrectomy;
FBG: Fasting blood glucose; PPG: Post prandial glucose; GLP-1: Glucagon-like peptide 1; BMl: Body mass index.

\section{Competing interests}

The authors declared that they have no competing interests.

\section{Authors' contributions}

SHR has participated in the study design, and has given the final approval of the version to be published. Also, MP has written the first draft.

\section{Authors' information}

1. Shirin Hasani-Ranjbar: Associate Professor, Endocrinology and metabolism, Tehran University of Medical Sciences, Iran

2. Moloud Payab: Master of Health Science in Nutrition, PhD Student of

Obesity \& Eating Habits Research Center

\section{Acknowledgment}

Implementation of this study was sponsored by Tehran University of Medical Sciences (Endocrinology and Metabolism Research institute).

Received: 2 September 2015 Accepted: 5 September 2015

Published online: 07 October 2015

\section{References}

1. Jafari-Adli S, Jouyandeh Z, Qorbani M, Soroush A, Larijani B, Hasani-Ranjbar S. Prevalence of obesity and overweight in adults and children in Iran; a systematic review. J Diabetes Metab Disord. 2014;13(1):121.

2. Payab M, Hasani-Ranjbar S, Larijani B. Whether all obese subjects both in metabolic groups and non-metabolic groups should be treated or not. J Diabetes Metab Disord. 2014;13(1):21.

3. Shaw JE, Sicree RA, Zimmet PZ. Global estimates of the prevalence of diabetes for 2010 and 2030. Diabetes Res Clin Pract. 2010;87(1):4-14.

4. Whiting DR, Guariguata L, Weil C, Shaw J. IDF diabetes atlas: global estimates of the prevalence of diabetes for 2011 and 2030. Diabetes Res Clin Pract. 2011;94(3):311-21.

5. Hasani-Ranjbar S, Larijani B, Abdollahi M. A systematic review of the potential herbal sources of future drugs effective in oxidant-related diseases. Inflamm Allergy Drug Targets. 2009;8(1):2-10.

6. Hasani-Ranjbar S, Zahedi HS, Abdollahi M, Larijani B. Trends in publication of evidence-based Traditional Iranian medicine in endocrinology and metabolic disorders. J Diabetes Metab Disord. 2013;12(1):49.

7. Buchwald H, Estok R, Fahrbach K, Banel D, Jensen MD, Pories WJ, et al. Weight and type 2 diabetes after bariatric surgery: systematic review and meta-analysis. Am J Med. 2009;122(3):248-56. e5.

8. Ugale S, Gupta N, Modi KD, Kota SK, Satwalekar V, Naik V, et al. Prediction of remission after metabolic surgery using a novel scoring system in type 2 diabetes-a retrospective cohort study. J Diabetes Metab Disord. 2014;13(1):89.

9. Kumar KV, Ugale S, Gupta N, Naik V, Kumar P, Bhaskar P, et al. lleal interposition with sleeve gastrectomy for control of type 2 diabetes. Diabetes Technol Ther. 2009;11(12):785-9.

10. Greenway SE, Greenway 3rd FL, Klein S. Effects of obesity surgery on noninsulin-dependent diabetes mellitus. Arch Surg. 2002:137(10):1109-17.

11. Kota SK, Ugale S, Gupta N, Naik V, Kumar KV, Modi KD. Ileal interposition with sleeve gastrectomy for treatment of type 2 diabetes mellitus. Indian J Endocrinol Metab. 2012;16(4):589-98.

12. Kota SK, Ugale S, Gupta N, Naik V, Kota SK, Kumar KH, et al. Remission of type 2 diabetes mellitus by ileal interposition with sleeve gastrectomy. Int J Endocrinol Metab. 2011;9(3):374-81.

13. Cummings DE, Overduin J, Foster-Schubert KE. Gastric bypass for obesity: mechanisms of weight loss and diabetes resolution. J Clin Endocrinol Metab. 2004:89(6):2608-15

14. Boza C, Gagner M, Devaud N, Escalona A, Munoz R, Gandarillas M. Laparoscopic sleeve gastrectomy with ileal transposition (SGIT): A new surgical procedure as effective as gastric bypass for weight control in a porcine model. Surg Endosc. 2008;22(4):1029-34.

15. Misra A, Chowbey P, Makkar BM, Vikram NK, Wasir JS, Chadha D, et al. Consensus statement for diagnosis of obesity, abdominal obesity and the metabolic syndrome for Asian Indians and recommendations for physical activity, medical and surgical management. J Assoc Physicians India. 2009;57:163-70. 
16. De Paula AL, Stival AR, Macedo A, Ribamar J, Mancini M, Halpern A, et al.

Prospective randomized controlled trial comparing 2 versions of laparoscopic ileal interposition associated with sleeve gastrectomy for patients with type 2 diabetes with BMI $21-34 \mathrm{~kg} / \mathrm{m}(2)$. Surg Obes Relat Dis. 2010;6(3):296-304.

17. DePaula AL, Macedo AL, Mota BR, Schraibman V. Laparoscopic ileal interposition associated to a diverted sleeve gastrectomy is an effective operation for the treatment of type 2 diabetes mellitus patients with BMI 21-29. Surg Endosc. 2009;23(6):1313-20.

18. DePaula AL, Macedo AL, Rassi N, Machado CA, Schraibman V, Silva LQ, et al. Laparoscopic treatment of type 2 diabetes mellitus for patients with a body mass index less than 35. Surg Endosc. 2008;22(3):706-16.

19. Strader AD, Vahl TP, Jandacek RJ, Woods SC, D'Alessio DA, Seeley RJ. Weight loss through ileal transposition is accompanied by increased ileal hormone secretion and synthesis in rats. Am J Physiol Endocrinol Metab. 2005;288(2):E447-53.

20. Holst JJ. The physiology of glucagon-like peptide 1. Physiol Rev. 2007:87(4):1409-39.

21. Vilsboll T, Holst JJ. Incretins, insulin secretion and Type 2 diabetes mellitus. Diabetologia. 2004;47(3):357-66

22. Pereferrer FS, Gonzalez MH, Rovira AF, Blasco SB, Rivas AM, del Castillo DD. Influence of sleeve gastrectomy on several experimental models of obesity: metabolic and hormonal implications. Obes Surg. 2008;18(1):97-108.

23. Tinoco A, El-Kadre L, Aquiar L, Tinoco R, Savassi-Rocha P. Short-term and mid-term control of type 2 diabetes mellitus by laparoscopic sleeve gastrectomy with ileal interposition. World J Surg. 2011;35(10):2238-44

24. Williams DL, Cummings DE. Regulation of ghrelin in physiologic and pathophysiologic states. J Nutr. 2005;135(5):1320-5.

25. Kota SK, Ugale S, Gupta N, Modi KD. Laparoscopic ileal interposition with diverted sleeve gastrectomy for treatment of type 2 diabetes. Diabetol Metab Syndr. 2012;6(3):125-31.

26. Dixon JB, Chuang LM, Chong K, Chen SC, Lambert GW, Straznicky NE, et al. Predicting the glycemic response to gastric bypass surgery in patients with type 2 diabetes. Diabetes Care. 2013;36(1):20-6.

27. Lee WJ, Ser KH, Chong K, Lee YC, Chen SC, Tsou JJ, et al. Laparoscopic sleeve gastrectomy for diabetes treatment in nonmorbidly obese patients: efficacy and change of insulin secretion. Surgery. 2010;147(5):664-9.

28. Cryer PE. Hypoglycaemia: the limiting factor in the glycaemic management of Type I and Type || diabetes. Diabetologia. 2002;45(7):937-48.

\section{Submit your next manuscript to BioMed Central and take full advantage of:}

- Convenient online submission

- Thorough peer review

- No space constraints or color figure charges

- Immediate publication on acceptance

- Inclusion in PubMed, CAS, Scopus and Google Scholar

- Research which is freely available for redistribution 